\title{
Natural and artificial radioactivity levels and hazards of soils in the Kücük Menderes Basin, Turkey
}

\author{
Serpil Aközcan
}

Received: 12 March 2013/Accepted: 6 October 2013/Published online: 23 October 2013

(c) The Author(s) 2013. This article is published with open access at Springerlink.com

\begin{abstract}
In this study, natural and artificial radionuclide activity concentrations in surface soils of Kücük Menderes Basin have been measured using gamma spectroscopy. The soil samples were collected from agricultural lands in the Kücük Menderes Basin in Turkey. The activity concentrations of ${ }^{226} \mathrm{Ra},{ }^{232} \mathrm{Th},{ }^{40} \mathrm{~K}$ and ${ }^{137} \mathrm{Cs}$ in the soils were found to be range of $12.63 \pm 2.28-72.51 \pm 11.23,11.45 \pm 2.4$ $58.12 \pm 4.76,234.8 \pm 14.85-1058.52 \pm 24 \mathrm{~Bq} \mathrm{~kg}^{-1} \mathrm{dw}$ and $2.31 \pm 0.18-7.75 \pm 1.14 \mathrm{~Bq} \mathrm{~kg}^{-1}$, respectively. The natural gamma radioactivity of the terrestrial radionuclides in soil samples and the gamma absorbed dose rate, the annual effective dose equivalent, the radium equivalent activity, the external hazard index, were calculated and compared with the international recommended values.
\end{abstract}

Keywords Radionuclide $\cdot$ Soil $\cdot$ Kucuk Menderes

Basin · Dose rate

\section{Introduction}

Humans are exposed to background radiation that stems both from natural and artificial sources (Taskin et al. 2009). The two significant natural sources of external radiation to which human are exposed are cosmic rays and terrestrial gamma rays. Terrestrial gamma rays are essentially due to radionuclides belonging to uranium-238 $\left({ }^{238} \mathrm{U}\right)$ and thorium-232 $\left({ }^{232} \mathrm{Th}\right)$ series and singly occurring potassium-40 $\left({ }^{40} \mathrm{~K}\right)$ that are present in the earth's crust (Murty and Karunakara 2008). Artificial radionuclides can also be present like Caesium-137 $\left({ }^{137} \mathrm{Cs}\right)$ is a fission product which

S. Aközcan $(\square)$

Department of Physics, Kirklareli University,

Campus of Kavakli, Kirklareli, Kavakli, Turkey

e-mail: sakozcan35@yahoo.com is formed through nuclear weapon tests and nuclear power plant accidents (Kurnaz et al. 2011).

Distributions of ${ }^{238} \mathrm{U},{ }^{226} \mathrm{Ra},{ }^{232} \mathrm{Th}$ and ${ }^{40} \mathrm{~K}$ in soils depend on the radionuclide distribution in rocks from which they originate and on the processes through which the soils are concentrated (Song et al. 2012). Soil is the most important source of terrestrial gamma radiation levels, containing trace quantities of terrestrial radionuclides, whose concentrations depend on the local geology of each region in the world (UNSCEAR 2000; Montes et al. 2012; Turhan et al. 2012).

The main objective of this study is to: (i) determine the concentration of natural and artificial radionuclides $\left({ }^{226} \mathrm{Ra}\right.$, ${ }^{232} \mathrm{Th},{ }^{40} \mathrm{~K}$ and ${ }^{137} \mathrm{Cs}$ ) in the soil of Kucuk Menderes River Basin, Aegean Region, Turkey; (ii) calculate the important radiological parameters to assess the complete radiological hazardous nature of the soils.

\section{Materials and methods}

Study area

Kucuk Menderes River Basin, covering about 3,500 km² area, extends westwards towards Aegean Region (Fig. 1). The region is located at western part of Turkey. Kucuk Menderes basin is a very productive agricultural area, with industrial sites concentrated in the west. Almost all irrigation and industrial water needs in the basin have been supplied using groundwater resources (Pusatli et al. 2009).

Sample collection and preparation for gamma ray spectrometry

Surface soil samples at $0-5 \mathrm{~cm}$ depth level weighing from to 1.5 to $2 \mathrm{~kg}$ were collected from 40 sites on the Kücük 
Fig. 1 Map of the study area

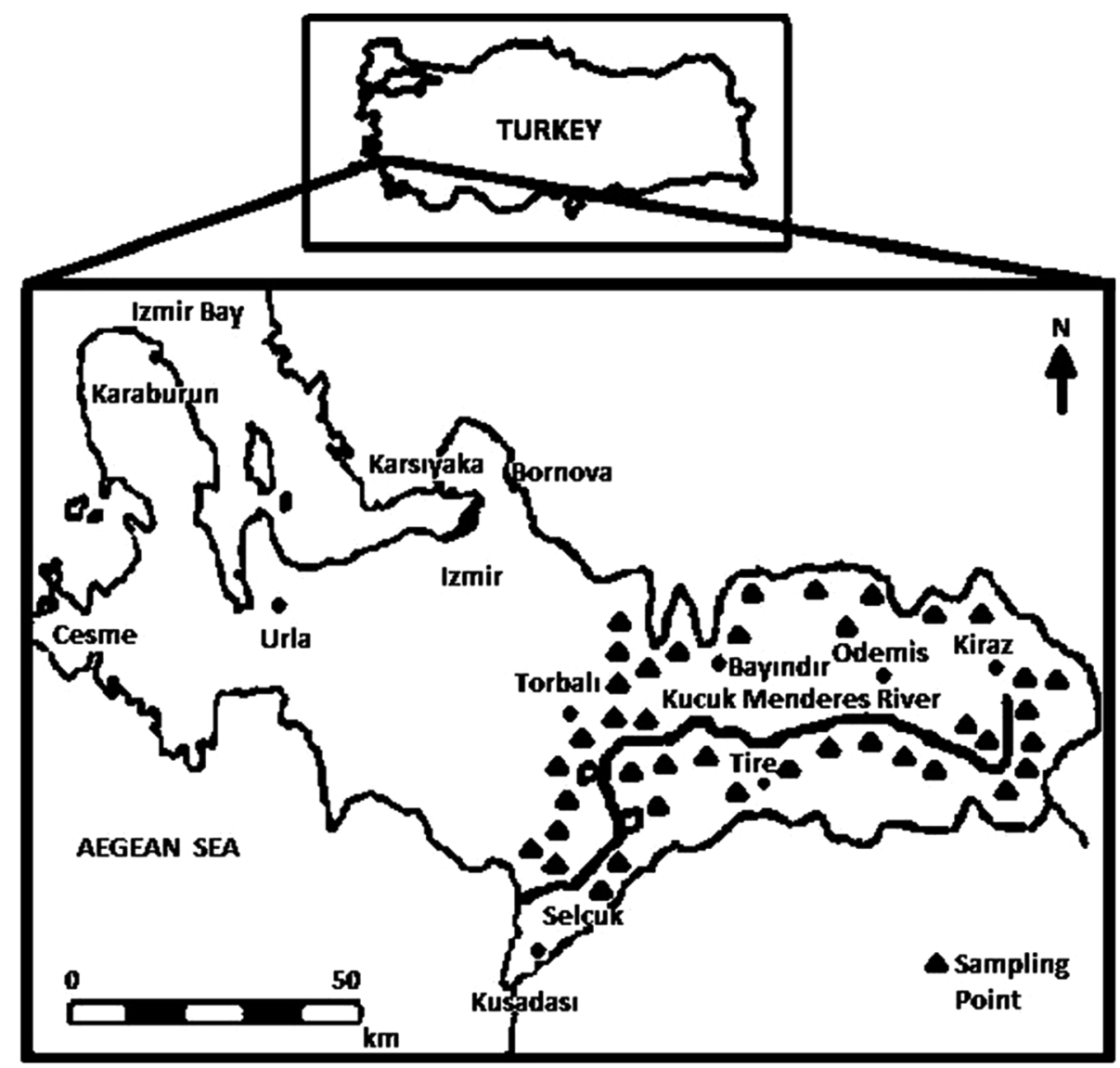

Menderes River, in August 2010. Samples were dried in an oven at about $105{ }^{\circ} \mathrm{C}$ for $24 \mathrm{~h}$, pulverized, homogenized and sieved through $2 \mathrm{~mm}$ mesh. All samples were transferred to containers, weighed, hermetically sealed and stored for 4 weeks to ensure that ${ }^{238} \mathrm{U}$ and ${ }^{232} \mathrm{Th}$ attained the secular equilibrium with their short-lived decay products (Turhan et al. 2012).

Gamma ray spectrometry system

Measurement of the natural radioactivity $\left({ }^{226} \mathrm{Ra},{ }^{232} \mathrm{Th}\right.$ and ${ }^{40} \mathrm{~K}$ ) and ${ }^{137} \mathrm{Cs}$ in the soil samples was conducted with the high-resolution gamma ray spectrometers with p-type coaxial HPGe detector. A solid nuclide mixture of gamma reference calibration source from Isotope Product Laboratories (containing the radionuclides ${ }^{241} \mathrm{Am},{ }^{109} \mathrm{Cd},{ }^{57} \mathrm{Co}$, ${ }^{123 \mathrm{~m}} \mathrm{Te},{ }^{51} \mathrm{Cr},{ }^{113} \mathrm{Sn},{ }^{85} \mathrm{Sr},{ }^{137} \mathrm{Cs},{ }^{88} \mathrm{Y},{ }^{60} \mathrm{Co}$ peaks for energy range between 80 and 2,500 keV) was used for the fullenergy peak (FEP) efficiency calibration. Each sample was measured for an accumulating time between 12 and $24 \mathrm{~h}$. Background measurements were taken under the same conditions of sample measurements and subtracted in order to get net counts for the sample. The activity concentrations of ${ }^{232} \mathrm{Th}$ and ${ }^{238} \mathrm{U}$ were calculated assuming secular equilibrium being established with their decay products.
The gamma-ray line of the $351.9 \mathrm{keV}$ from ${ }^{214} \mathrm{~Pb}$ and the $609.3 \mathrm{keV}$ from ${ }^{214} \mathrm{Bi}$ were used to determine the activity concentration of ${ }^{226} \mathrm{Ra}$. The gamma-ray line of the $911.1 \mathrm{keV}$ from ${ }^{228} \mathrm{Ac}$ and the $583.1 \mathrm{keV}$ from ${ }^{208} \mathrm{Tl}$ were used to determine the activity concentration of ${ }^{232} \mathrm{Th}$. The activity of ${ }^{40} \mathrm{~K}$ and ${ }^{137} \mathrm{Cs}$ were evaluated using its 1,460 and $662 \mathrm{keV}$ peaks.

The detection limits were estimated to be $3.4 \mathrm{~Bq} \mathrm{~kg}^{-1}$ for ${ }^{226} \mathrm{Ra}, 5.2 \mathrm{~Bq} \mathrm{~kg}^{-1}$ for ${ }^{232} \mathrm{Th}, 10.1 \mathrm{~Bq} \mathrm{~kg}{ }^{-1}$ for ${ }^{40} \mathrm{~K}$ and $1.0 \mathrm{~Bq} \mathrm{~kg}{ }^{-1}$ for ${ }^{137} \mathrm{Cs}$.

\section{Results and discussions}

The results of activity concentrations in soil samples collected from the studied site (Kucuk Menderes River Basin) varied from 13 to $73 \mathrm{~Bq} \mathrm{~kg}^{-1}$ for ${ }^{226} \mathrm{Ra}, 11$ to $58 \mathrm{~Bq} \mathrm{~kg}^{-1}$ for ${ }^{232} \mathrm{Th}, 235$ to $1,059 \mathrm{~Bq} \mathrm{~kg}^{-1}$ for ${ }^{40} \mathrm{~K}$ and 2 to $8 \mathrm{~Bq} \mathrm{~kg}^{-1}$ for ${ }^{137} \mathrm{Cs}$.

The average concentrations found in this study are 48.35, 20.48, 744.76 and $3.31 \mathrm{~Bq} \mathrm{~kg}^{-1}$, respectively, although the average concentrations obtained in surface soil samples in this study are comparable to those from some cities in Turkey and world (Table 1). The concentrations of the radionuclides ${ }^{226} \mathrm{Ra},{ }^{232} \mathrm{Th}$ and ${ }^{40} \mathrm{~K}$ in the 
Table 1 Comparison of the activity concentrations of the ${ }^{226} \mathrm{Ra},{ }^{232} \mathrm{Th},{ }^{40} \mathrm{~K}$ and ${ }^{137} \mathrm{Cs}(\mathrm{dw})$ in soil samples with values reported for different regions of Turkey and different countries

\begin{tabular}{llllll}
\hline Region & ${ }^{226} \mathrm{Ra}\left(\mathrm{Bq} \mathrm{kg}^{-1}\right)$ & $\left.{ }^{232} \mathrm{Th}_{(\mathrm{Bq} \mathrm{kg}}{ }^{-1}\right)$ & ${ }^{40} \mathrm{~K}_{\left(\mathrm{Bq} \mathrm{kg}^{-1}\right)}$ & ${ }^{137}{\mathrm{Cs}\left(\mathrm{Bq} \mathrm{kg}^{-1}\right)}^{\text {References }}$ \\
\hline Tripoli/Libya & 10.5 & 9.5 & 270 & & Shenber (1997) \\
Jordan & 52.9 & 24.0 & 442.6 & - & Ahmad and Hussein (1998) \\
Istanbul/Turkey & - & 37 & 342 & 18 & Karahan and Bayulken (2000) \\
India & - & 119 & 406 & - & Kannan et al. (2002) \\
Tekirdağ/Turkey & - & 39 & 579 & 5 & Yarar and Kam (2005) \\
Manisa/Turkey & - & 27 & 340 & - & Erees et al. (2006) \\
Kastamonu/Turkey & 37.4 & 27.2 & 431.4 & 8.0 & Kam and Bozkurt (2007) \\
Rize/Turkey & - & 42 & 653 & 85 & Kurnaz et al. (2007) \\
Sanlıurfa/Turkey & - & 25.0 & 298.6 & 9.1 & Bozkurt et al. (2007) \\
Kirklareli/Turkey & 37 & 40 & 667 & 8 & Taskin et al. (2009) \\
Bakırçay River/Turkey & 74.4 & 30.7 & 288 & - & Saç et al. (2012) \\
Kucuk Menderes River/Turkey & 48.4 & 20.5 & 744.8 & 3.3 & Present study
\end{tabular}

world have averages in soil of 35,30 and $400 \mathrm{~Bq} \mathrm{~kg}^{-1}$, respectively (UNSCEAR 2000). The mean activity concentration of ${ }^{226} \mathrm{Ra}$ and ${ }^{40} \mathrm{~K}$ is higher than the reported International Limits. The artificial radioactive compound, ${ }^{137} \mathrm{Cs}$ isotope does not exist in soil naturally and it is a product of fallout radioactivity (Karahan and Bayulken 2000). In the present study the highest recorded value of ${ }^{137} \mathrm{Cs}$ equals $8 \mathrm{~Bq} \mathrm{~kg}{ }^{-1}$.

The external terrestrial gamma radiation absorbed dose in air at $1 \mathrm{~m}$ above the ground level is calculated by using the following equation (UNSCEAR 2000; Kurnaz et al. 2007):

$$
\begin{aligned}
\mathrm{D}\left(\mathrm{nGyh}^{-1}\right)= & 0.462 \mathrm{C}_{\mathrm{Ra}}+0.604 \mathrm{C}_{\mathrm{Th}}+0.0417 \mathrm{C}_{\mathrm{K}} \\
& +0.03 \mathrm{C}_{\mathrm{Cs}}
\end{aligned}
$$

where $\mathrm{D}$ is the total absorbed dose rate (D) in air at $1 \mathrm{~m}$ above ground level; $\mathrm{C}_{\mathrm{Ra}}, \mathrm{C}_{\mathrm{Th}}, \mathrm{C}_{\mathrm{K}}$ and $\mathrm{C}_{\mathrm{Cs}}$ are the activity concentrations $\left(\mathrm{Bq} \mathrm{kg}{ }^{-1}\right.$ ) of ${ }^{226} \mathrm{Ra},{ }^{232} \mathrm{Th},{ }^{40} \mathrm{~K}$ and ${ }^{137} \mathrm{Cs}$, respectively.

The absorbed gamma D's in air at Kucuk Menderes Basin for soil samples are found between 22.62 and 112.97 $\mathrm{nGyh}^{-1}$. The mean absorbed gamma D in air was calculated as $66.77 \mathrm{nGyh}^{-1}$ and found to be comparable to the world average of $59 \mathrm{nGyh}^{-1}$ (UNSCEAR 2000).

The average $\mathrm{D}$ value was calculated as $65,60.9,59,56.8$ $\mathrm{nGy} / \mathrm{h}$, in Istanbul (Karahan and Bayulken 2000), in Sanliurfa (Bozkurt et al. 2007), in Trabzon (Kurnaz et al. 2011), in Bakırcay (western Turkey) (Saç et al. 2012), respectively. These average values in general are similar to our result.

To estimate the annual effective D's, the conversion coefficient of $0.7 \mathrm{~Sv} \mathrm{~Gy}^{-1}$ from absorbed dose in air to effective dose received by adults, and 0.2 for the outdoor occupancy factor were used according to UNSCEAR (2000).
The annual effective dose equivalent (AEDE) given by UNSCEAR (2000) was calculated from the equation:

$$
\begin{aligned}
(\mathrm{AEDE})\left(\mathrm{mSv} \mathrm{y}^{-1}\right)= & \mathrm{D}\left(\mathrm{nGy} \mathrm{h}^{-1}\right) \times 8,760\left(\mathrm{~h} \mathrm{y}^{-1}\right) \\
& \times 0.2 \times 0.7\left(\mathrm{~Sv} \mathrm{~Gy}^{-1}\right) \times 10^{-6} .
\end{aligned}
$$

The calculated values of annual effective dose due to gamma radiation range from 0.03 to $0.14 \mathrm{mSv} \mathrm{y}^{-1}$ with a mean value of $0.08 \mathrm{mSv} \mathrm{y}^{-1}$ which is higher than the world average of $0.07 \mathrm{mSv} \mathrm{y}^{-1}$ (UNSCEAR 2000).

The distribution of ${ }^{226} \mathrm{Ra},{ }^{232} \mathrm{Th}$ and ${ }^{40} \mathrm{~K}$ in soil is not uniform. Uniformity with respect to radiation exposure has been defined in terms of radium equivalent activity $\left(\mathrm{Ra}_{\mathrm{eq}}\right)$ in $\mathrm{Bq} \mathrm{kg}{ }^{-1}$. Radium equivalent activity is a widely used hazard index, with a formula for comparing the specific activity of materials containing different amounts of ${ }^{226} \mathrm{Ra}$, ${ }^{232} \mathrm{Th}$ and ${ }^{40} \mathrm{~K}$ (Abdi et al. 2009). The $\mathrm{Ra}_{\mathrm{eq}}$ calculated by (Beretka and Mathew 1985):

$\mathrm{Ra}_{\mathrm{eq}}\left(\mathrm{Bq} \mathrm{kg}^{-1}\right)=\mathrm{C}_{\mathrm{Ra}}+1.43 \mathrm{C}_{\mathrm{Th}}+0.07 \mathrm{C}_{\mathrm{K}}$.

where $\mathrm{C}_{\mathrm{Ra}}, \mathrm{C}_{\mathrm{Th}}$ and $\mathrm{C}_{\mathrm{K}}$ are the activity concentrations of ${ }^{226} \mathrm{Ra},{ }^{232} \mathrm{Th}$ and ${ }^{40} \mathrm{~K}$, respectively.

The average $\mathrm{Ra}_{\mathrm{eq}}$ was calculated as $129.8 \mathrm{~Bq} \mathrm{~kg}^{-1}$, which is within the range of $45.44-229.7 \mathrm{~Bq} \mathrm{~kg}^{-1}$. The estimated values of $\mathrm{Ra}_{\mathrm{eq}}$ in the present study are lower than the recommended maximum value of $370 \mathrm{~Bq} \mathrm{~kg}^{-1}$ (Kurnaz et al. 2007; Baykara et al. 2011).

The external hazard index $\left(\mathrm{H}_{\mathrm{ex}}\right)$ is defined as follows (Sroor et al. 2002):

$\mathrm{H}_{\mathrm{ex}}=\mathrm{C}_{\mathrm{Ra}} / 370+\mathrm{C}_{\mathrm{Th}} / 259+\mathrm{C}_{\mathrm{K}} / 4,810$.

where $\mathrm{C}_{\mathrm{Ra}}, \mathrm{C}_{\mathrm{Th}}$ and $\mathrm{C}_{\mathrm{K}}$ are the activity concentrations of ${ }^{226} \mathrm{Ra},{ }^{232} \mathrm{Th}$ and ${ }^{40} \mathrm{~K} \mathrm{~Bq} \mathrm{~kg}{ }^{-1}$, respectively. The results range from 0.13 to 0.64 and average value was found to be 0.37 . The average values of $H_{\text {ex }}$ were found to be 0.99 for 
Eskisehir/Turkey (Orgun et al. 2005), 0.45 for Rize/Turkey (Kurnaz et al. 2007), and 1.2 for China (Song et al. 2012).

\section{Conclusion}

In this study, the distributions of terrestrial and artificial radionuclides in the soil samples from 40 areas of Kucuk Menderes River Basin, Western Turkey (Aegean Region) were determined using gamma ray spectrometry with HPGe detector. The results showed that the mean concentrations of the ${ }^{226} \mathrm{Ra},{ }^{232} \mathrm{Th},{ }^{40} \mathrm{~K}$ and ${ }^{137} \mathrm{Cs}$ in soil samples are comparable to the reported literature values. From the measured values, the average values of absorbed gamma dose rate in air (D), AEDE, the $\mathrm{Ra}_{\mathrm{eq}}$, the $\mathrm{H}_{\mathrm{ex}}$ were calculated. The estimated average air-absorbed $\mathrm{D}$ and annual effective dose for all samples are $67 \mathrm{nGy} \mathrm{h}{ }^{-1}$ and $0.08 \mathrm{mSv}$, respectively. All the calculated external hazard indices were found to be $<1$, indicating a low dose.

This study may be used as a baseline for future investigations.

Open Access This article is distributed under the terms of the Creative Commons Attribution License which permits any use, distribution, and reproduction in any medium, provided the original author(s) and the source are credited.

\section{References}

Abdi MR, Hassanzadeh S, Kamali M, Raji HR (2009) ${ }^{238} \mathrm{U},{ }^{232} \mathrm{Th}$, ${ }^{40} \mathrm{~K}$ and ${ }^{137} \mathrm{Cs}$ activity concentrations along the southern coast of the Caspian Sea. Iran Mar Pollut Bull 58:658-662

Ahmad N, Hussein AJA (1998) radiation doses in jordanian dwellings due to natural radioactivity in construction materials and soil. Environ Radioactivity 41(2):127-136

Baykara O, Karatepe Ş, Doğru M (2011) Assessments of natural radioactivity and radiological hazards in construction materials used in Elazig, Turkey. Radiat Meas 46:153-158

Beretka J, Mathew PJ (1985) Natural radioactivity of Australian building materials, industrial wastes and byproducts. Health Phys 48:87-95

Bozkurt A, Yorulmaz N, Kam E, Karahan G, Osmanlioglu AE (2007) Assessment of environmental radioactivity for Sanliurfa region of Southeastern Turkey. Radiat Meas 42:1387-1391

Erees, FS, Aközcan S, Parlak Y, Cam S (2006) Assessment of dose rates around Manisa (Turkey). Radiat Meas 41:598-601
Kam E, Bozkurt A (2007) Environmental radioactivity measurements in Kastamonu region of northern Turkey. Appl Radiat Isot 65:440-444

Kannan V, Rajan MP, Iyengar MAR, Ramesh R (2002) Distribution of natural and anthropogenic radionuclides in soil and beach sand samples of Kalpakkam (India) using hyperpure germanium (HPGe) gamma ray spectrometry. Appl Radiat Isot 57:109-119

Karahan G, Bayulken A (2000) Assessment of gamma dose rates around Istanbul (Turkey). J Environ Radioact 47:213-221

Kurnaz A, Küçükömeroglu B, Keser R, Okumusoglu NT, Korkmaz F, Karahan G, Çevik U (2007) Determination of radioactivity levels and hazards of soil and sediment samples in Firtına Valley (Rize, Turkey). Appl Radiat Isot 65:1281-1289

Kurnaz A, Kucukomeroglu B, Damla N, Cevik U (2011) Radiological maps for Trabzon, Turkey. J Environ Radioact 102:393-399

Montes ML, Mercader RC, Taylor MA, Runco J, Desimoni J (2012) Assessment of natural radioactivity levels and their relationship with soil characteristics in undisturbed soils of the northeast of Buenos Aires province, Argentina. J Environ Radioact 105:30-39

Murty VRK, Karunakara N (2008) Natural radioactivity in the soil samples of Botswana. Radiat Meas 43:1541-1545

Orgun Y, Altınsoy N, Gultekin AH, Karahan G, Celebi N (2005) Natural radioactivity levels in granitic plutons and groundwaters in Southeast part of Eskisehir, Turkey. Appl Radiat Isot 63:267-275

Pusatli OT, Camur MZ, Yazicigil H (2009) Susceptibility indexing method for irrigation water management planning: applications to K. Menderes river basin, Turkey. J Environ Manage 90(1):341-347

Saç MM, Ortabuk F, Kumru MN, İçhedef M, Sert Ş (2012) Determination of radioactivity and heavy metals of Bakirçay river in Western Turkey. Appl Radiat Isot 70(10):2494-2499

Shenber MA (1997) Measurement of natural radioactivity levels in soil in tripoli. Appl Radiat Isot 48:147-148

Song G, Chen D, Tang Z, Zhang Z, Xie W (2012) Natural radioactivity levels in topsoil from the Pearl River Delta Zone, Guangdong, China. J Environ Radioact 103:48-53

Sroor A, Afifi SY, Abdel-Haleem AS, Salman AB, Abdel-Sammad M (2002) Environmental pollutant isotope measurements and natural radioactivity assessment for North Tushki area, south Western desert, Egypt. Appl Radiat Isot 57(3):427-436

Taşkın H, Karavus M, Ay P, Topuzoğlu A, Hidiroğlu S, Karahan G (2009) Radionuclide concentrations in soil and lifetime cancer risk due to gamma radioactivity in Kirklareli, Turkey. J Environ Radioact 100:49-53

Turhan Ş, Köse A, Varinlioğlu A, Şahin NK, Arıkan İ, Oğuz F, Yücel B, Özdemir T (2012) Distribution of terrestrial and anthropogenic radionuclides in Turkish surface soil samples. Geoderma 187-188:117-124

UNSCEAR (2000) United Nations Scientific Committee on the Effect of Atomic Radiation, Sources and Effects of Ionizing Radiation. Report to the General Assembly. United Nations, New York

Yarar Y, Kam E (2005) Environmental radioactivity concentrations of Tekirdag. Int Congr Ser 1276:387-389 